\title{
Haemolysis related to mitral valve replacement with the Beall valve prosthesis
}

\author{
B. J. HENDERSON, A. S. MITHA, B. T. le ROUX, and \\ M. S. G O T S M A N \\ Cardiac and Thoracic Surgical Units, University of Natal, Wentworth Hospital, \\ Durban, South Africa
}

\begin{abstract}
Henderson, B. J., Mitha, A. S., le Roux, B. T., and Gotsman, M. S. (1973). Thorax, 28, 488-491. Haemolysis related to mitral valve replacement with the Beall valve prothesis. Experience of valve replacement with the Beall compressed Teflon disc valve in 59 patients confirms that the incidence of clinically significant late red cell destruction is high. An apparently previously unrecorded high incidence of early haemolysis, so severe in one patient as to be directly the cause of death, is reported. In 29 patients there was massive haemolysis in early convalescence, not recognized in urine from some hours after the end of bypass and never encountered with other designs of prosthetic valve or homograft valve.
\end{abstract}

By December 1971, 10,000 Beall Teflon disc mitral valve prostheses had been delivered by the manufacturers. There are a number of reports of the results of mitral valve replacement with this prosthesis which testify to the haemodynamic acceptability of the valve (Linhart et al., 1969 ; Vogel et al., 1971) and the low incidence of early and late postoperative thromboembolic episodes (Beall et al., 1968 ; Javier et al., 1970). Disc variance, reported as a complication of those valves manufactured before 1968, the disc of which was of extruded Teflon (Beall, Bricker, and Messmer, 1970; Robinson, Hildner, and Greenberg, 1971), was thought to be less likely when the disc was replaced by a significantly more dense, compression-moulded Teflon twice as thick as that previously used. However, Berroya and Escano (1972) report two examples of variance of the newer, thicker, compression-moulded discs. Still more recently, the problem of disc variance is believed to have been overcome by the use of Pyrolite carbon (Beall et al., 1972).

While accepting that the valve is now likely to be durable, that the thromboembolic complication rate is low, and that the haemodynamic efficiency, at least at rest, is adequate, the haemolytic effects of the valve are less acceptable (Williams et al., 1971). Haemolysis has long been recognized as a complication of prosthetic valve replacement, and this problem was recently summarized in an editorial in the Lancet (1972). Minor degrees of haemolysis are known to occur with all varieties of prosthetic valve, especially in the aortic position, $\stackrel{\circ}{\circ}$ and when more than one valve is replaced. Clinic- $\mathbb{D}$ ally significant haemolysis has, however, been un- $\overrightarrow{\vec{O}}$ usual without partial detachment of a prosthesis 3 and perivalvular incompetence. There is strong evidence that valve prostheses which incorporate Dacron velour predispose to excessive intravascular haemolysis in the absence of prosthetic dysfunction 음 or incompetence, both in patients (Milam, Blood- ֻ well, Hallman, and Cooley, 1969) and in experi- $\frac{\dot{0}}{3}$ mental animals (Magovern et al., 1970), and the haemolytic effects of Dacron velour heavily out- o weigh the incompletely proven advantages of rapid tissue ingrowth in this material.

The purpose of this paper is to outline clinical $D$ experience of valve replacement with the Beall

T A B LE I

BEALl VALVES (Sepiember 1971 to August 1972)

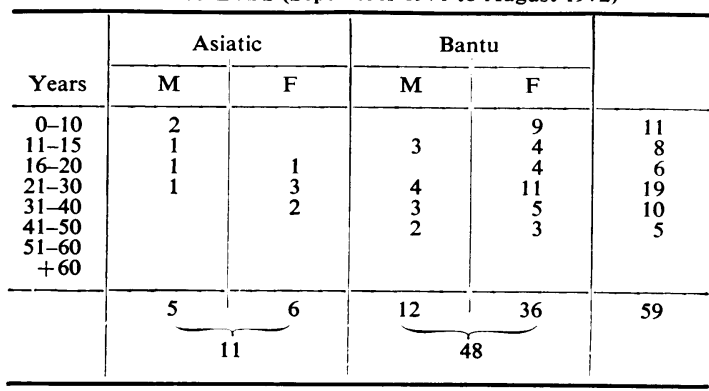


T A B L E II

MITRAL VALVE REPLACEMENT 292/900

\begin{tabular}{|c|c|c|c|c|c|c|c|c|c|c|c|}
\hline \multirow{2}{*}{ Years } & \multicolumn{2}{|c|}{ Caucasian } & \multicolumn{2}{|c|}{ Coloured } & \multicolumn{2}{|c|}{ Asiatic } & \multicolumn{2}{|c|}{ Bantu } & & & \\
\hline & $\mathbf{M}$ & $\mathbf{F}$ & $\mathbf{M}$ & $\mathbf{F}$ & $\mathbf{M}$ & $\mathbf{F}$ & $\mathbf{M}$ & $\mathbf{F}$ & & & \\
\hline \multirow[t]{2}{*}{$\begin{array}{r}0-10 \\
11-15 \\
16-20 \\
21-30 \\
31-40 \\
41-50 \\
51-60 \\
+60\end{array}$} & $\begin{array}{l}1 \\
2 \\
4 \\
4 \\
5 \\
3\end{array}$ & $\begin{array}{c}1 \\
2 \\
3 \\
7 \\
14 \\
7 \\
5\end{array}$ & $\begin{array}{l}1 \\
1 \\
1\end{array}$ & $\begin{array}{l}1 \\
2 \\
2 \\
2 \\
1\end{array}$ & $\begin{array}{l}2 \\
6 \\
5 \\
3 \\
8 \\
4 \\
2\end{array}$ & $\begin{array}{l}4 \\
5 \\
5 \\
5 \\
7 \\
2\end{array}$ & $\begin{array}{r}7 \\
13 \\
8 \\
20 \\
10 \\
6 \\
3\end{array}$ & $\begin{array}{r}18 \\
23 \\
12 \\
25 \\
15 \\
5\end{array}$ & $\begin{array}{l}\left.\begin{array}{l}33 \\
48\end{array}\right\}(21 \%) \\
35 \\
61 \\
51 \\
38 \\
18\} \\
8\}\end{array}$ & $\left.\begin{array}{l}116 \\
(40 \%)\end{array}\right\}$ & $\begin{array}{l}177 \\
(60 \%)\end{array}$ \\
\hline & 19 & 39 & 3 & 8 & 30 & 28 & & -98 & 292 & & \\
\hline Population ratio & & & & & & & & & & & \\
\hline
\end{tabular}

valve prosthesis and to emphasize the difference in the degree and pattern of blood destruction with this valve prosthesis in comparison with homograft and Starr-Edwards valve replacement in the same population groups.

\section{PATIENTS AND METHODS}

In the period September 1971 to August 1972, 60 Beall valves were placed in 59 patients, in one patient in the tricuspid ring only, in 57 patients in the mitral ring only, and in one patient in the mitral and tricuspid rings together. The age, sex, and race of these patients are shown in Table I. Most patients were younger than 30 years, and females predominate. The selection of patients for Beall mitral valve replacement is representative since, of a total experience in four years, of nearly 300 mitral valve replacements $60 \%$ were younger than 30 years and $60 \%$ were females (Table II).

The indications for mitral valve replacement are shown in Table III. Pure mitral incompetence was

T A B LE III

MITRAL VALVE REPLACEMENT: BEALL VALVE

\begin{tabular}{|c|c|}
\hline Lesion corrected & No. of Patients \\
\hline 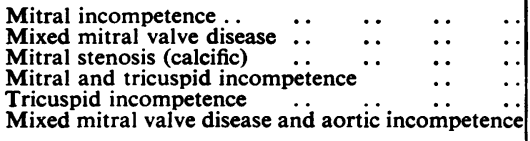 & $\begin{array}{r}31 \\
21 \\
4 \\
1 \\
1 \\
1\end{array}$ \\
\hline Total & 59 \\
\hline
\end{tabular}

the commonest, and mixed mitral valve disease and calcific mitral stenosis were only a little less common. In one patient the aortic valve was replaced with a Starr-Edwards prosthesis at the time of mitral valve replacement with a Beall valve. Isolated tricuspid valve replacement was necessary because clumsy repair of a ventricular septal defect two years earlier had, in this patient, induced severe tricuspid incompetence. In all other patients the valve lesion was rheumatic in origin. In three patients there was aortic incompetence judged not to need valve replacement. In two patients the tricuspid valve was inspected and the degree of tricuspid incompetence was judged likely further to regress after mitral valve replacement. Four patients had previously been submitted to closed mitral valvotomy. In two patients there was a large volume of clot in the left atrium. All patients were severely incapacitated before operation.

The approach was right-sided in all but two patients -in one in order to manage by decortication a chronic left pleural effusion at the time of mitral valve replacement, and in the other in the hope that the mitral valve lesion might be remediable by closed valvotomy. In 34 patients the large Beall valve was inserted, in 23 the medium valve, and in three the small valve. Two large valves were of the 'turtle neck' design, each inserted with a continuous suture; all the others were secured with interrupted Tycron.

In all patients the management of bypass was standard, using a haemodilution technique, a bubble (Temptrol or Travenol) oxygenator, and normal temperature. The duration of bypass varied from 21 to 60 minutes, and average bypass duration was 36 minutes. In most of the operations undertaken through a right thoracotomy the aorta was accessible for arterial inflow cannulation. The aorta was clamped between the valve and cannula during the period of left atriotomy, which was sited in front of the right pulmonary veins, and inspection and excision of the mitral valve. The aortic valve was then tripped and the aorta unclamped during placement of the sutures in the mitral annulus; the clamp was reapplied during seating of the valve. After all sutures had been tied, the disc was tripped, the left atrium partly repaired, and the cardiac chambers emptied of air, a manoeuvre which included aspiration of the base of the aorta, following which the aortic clamp was removed. Finally the trip was removed and the left atrial repair was completed. In those patients in whom mitral valve replacement was undertaken through a left thrra- 
cotomy, venous drainage was from the left femoral vein and the right ventricular outflow, and the arterial inflow was to the left femoral artery. Aortic clamping for the control of air followed the same routine as through a right thoracotomy; a left ventricular vent was used.

During the period when 60 Beall valves were inserted in 59 patients the mitral valve was replaced in 43 patients using a Starr-Edwards prosthesis and in 11 patients using homograft valves by the same group of surgeons and with a similar technique.

\section{RESULTS}

There was one operative and one early postoperative death; there have not been late postoperative deaths. The intraoperative death can be related directly to surgical error. The early postoperative death was the consequence of massive haemolysis, acute renal failure, and arrhythmia related to a rapidly rising blood potassium. Death occurred while preparations were being made for haemodialysis. This patient was the second in this series.

In 29 patients haemolysis occurred in early convalescence, never earlier that four hours after the end of bypass, unrelaied to time on bypass and valve size, sex or age of patient. The patientshalf the series, and haphazardly throughout the series - all had clear urine during and immediately after bypass. All had an indwelling urinary catheter. Four to eight hours after return to the intensive care ward the urine of these patients, in the space of 30 to 60 minutes, became dark red in colour and was shown to contain haemoglobin. Haemolysis continued for 2 to 30 hours after its first recognition. There was confirmatory evidence of an elevated, sometimes grossly elevated, serum haemoglobin in all these patients. In all patients the urine was normal after 48 hours, in most after 18 hours. Delay in the appearance of haemoglobin in the urine may reflect the time taken to saturate serum haptoglobulins.

In the patients submitted to mitral valve replacement with the Starr-Edwards prosthesis or a mounted aortic homograft during this period, and throughout an extensive experience of valve replacement before this period, this syndrome was not observed. Other aspects of technique were unchanged. Where haemolysis has occasionally been seen in the past in relation to an operation with cardiopulmonary bypass, this has been related to prolonged bypass and has begun intraoperatively and continued with progressive diminution into early convalescence. It seems reasonable to ascribe the pattern of early postoperative haemolysis and the one postoperative death to the design of the Beall valve Two patients developed a transient hemiplegiz 14 and 28 days, respectively, after valve replace $\underline{\underline{\underline{D}}}$ ment and these episodes are believed to have beerf embolic in origin.

Late postoperative red cell survival studies have्छ been undertaken in 17 patients. In the laboratory in which this examination was undertaken the normal effective half-life of labelled red cells is accepted as 26 to 30 days. In four patients red cell survival studies four to six months post $\vec{x}$ operatively, following Beall valve insertion, weri normal; in four patients red cell survival was re duced to 22 to 26 days; in four patients red celb survival was 18 to 22 days; in five patients redo cell survival was less than 18 days $(14,11,11,9$ 음 and 6 days respectively). There is no correlationbetween early postoperative haemoglobinuria ans late postoperative diminution in red cell survivals that is, patients in whom postoperative haemolysiso was dramatic have been shown to have normal red cell survival figures; two who did not experience early postoperative haemolysis have beep among those with the shortest red cel survival figures. Two patients have been admitteक in late convalescence with haemoglobin figures of 6 and $5.5 \mathrm{~g} \%$-both these were children who ha\& an associated iron deficiency with a low serun iron and an elevated total iron binding capacity? Two other patients with haemoglobin concen trations of 10 and $9.7 \mathrm{~g} \%$ respectively were work ing and leading a normal life.

Two patients in the series cannot be tracect Patients were not initially placed on oral irof therapy at the time of discharge; they are now Those patients who have been traced are well, well-being in those who were grossly anaemio having been restored by appropriate transfusiog and recourse to iron therapy.

Six patients have been catheterized in the pos operative period and have been shown to have gradients of 3 to $8 \mathrm{mmHg}$ across the valve at resf Of those submitted to postoperative investigation two had large valves, one a medium, and one small valve.

\section{COMMENT}

Mitral valve replacement is a safe and good operation. The ideal prosthetic valve has not yet been designed. It is doubtful whether any valve free from the complications of thromboembolisn structural failure, infection, and blood destruction While the design of the Beall valve has diminished the incidence of thromboembolism, its use to associated with high incidence of early and late postoperative haemolysis. Early postoperatio 
haemolysis is not recorded in other series either because it has not been recognized owing to the generally high incidence of postoperative haemolysis; because it has not occurred; or because it has not been reported. Late postoperative haemolysis is commonplace; of 12 patients recently recorded by Crexells et al. (1972), haemolysis was a feature in all, and in six this was severe. While the consequences of haemolysis, unlike those of thromboembolism, can be largely remedied by appropriate iron therapy, severe haemolysis is a serious disadvantage and carries a high incidence of significant renal damage. Greenberg (1970) has expressed the opinion that haemolysis in relation to the use of the Beall valve may diminish after the valve has been in situ for six months. If haemolysis is related to the use of Dacron velour it is clear that for this material the advantage of early tissue ingrowth cannot be claimed if haemolysis does in fact diminish only after six months.

\section{REFERENCES}

Beall, A. C. Jr., Bloodwell, R. D., Liotta, D., Cooley, D. A., and De Bakey, M. E. (1968). Clinical experience with a Dacron velour-covered Teflon-disc mitral-valve prosthesis. Annals of Thoracic Surgery, 5, 402.

, Bricker, D. L., and Messmer, B. J. (1970). Results of mitral valve replacement with Dacron velourcovered Teflon-disc prothesis. Annals of Thoracic Surgery, 9, 195.

—, Morris G. C. Jr., Noon, G. P., Guinn, G. A., Reul, G. J., Lefrak, E. A., and Greenberg, S. D. (1972). An improved mitral valve prosthesis. Presented at the 21st Annual Scientific Session of the American College of Cardiology, Chicago, Illinois. 4 March, 1972.

Berroya, R. B., and Escano, F. B. Jr. (1972). Mitral discvalve variance. Thorax, 27, 87.
Crexells, C., Aerichide, N., Bonny, Y., Lepage, G., and Campeau, L. (1972). Factors influencing haemolysis in valve prosthesis. American Heart Journal, 84, 161.

Greenberg, J. (1970). In discussion 'Cloth covered aortic and mitral valve prostheses'. Spencer, F. C., Reed, G. E., Clauss, R. H., Tice, D. A., and Reppert, E. H. Journal of Thoracic and Cardiovascular Surgery, 59, 107.

Javier, R. P., Hildner, F. J., Berry, W., Greenberg, J. J., and Samet, P. (1970). Systemic embolism and the Beall mitral valve prosthesis. Annals of Thoracic Surgery, $10,20$.

Lancet Editorial. (1972). Anaemia with artificial heartvalves. Lancet, 1, 1321.

Linhart, J. W., Barold, S. S., Hildner, F. J., Samet, P., Piccinini, J. C., Marsten, J. L., and Greenberg, J. J. (1969). Clinical and hemodynamic findings following replacement of the mitral valve with a Beall valve prosthesis (Dacron velour-covered Teflon-disc valve). Circulation, Suppl. 1, Vols 39 and 40, pp. 1-127.

Magovern, G. J., Begg. F. J., Kent, E. M., Cushing, W. B., Gerber, M. L., and Fisher, D. L. (1970). The experimental and clinical results of a modified cage disc mitral prosthesis. Journal of Thoracic and Cardiovascular Surgery, 59, 109.

Milam, J. D., Bloodwell, R. D., Hallman, G. L., and Cooley, D. A. (1969). Evaluation of hemolysis in patients with cardiac valve prostheses: A comparative study. In Prosthetic Heart Valves, edited by L. A. Brewer, chap. 47, p. 663. Thomas, Springfield, Illinois.

Robinson, M. J., Hildner, F. J., and Greenberg, J. J. (1971). Disc variance of Beall mitral valve, Annals of Thoracic Surgery, 11, 11.

Vogel, J. H. K., Paton, B. C., Overy, H. R., Pappas, G., Hywel Davies, D., and Blount, S. G. Jr. (1971). Advantages of the Beall valve prostheses. Chest, 59, 249.

Williams, J. C. Jr., Vernon, C. R., Daicoff, G. R., Bartley, T. D., Wheat, M. W. Jr., and Ramsey, H. W. (1971). Hemolysis following mitral valve replacement with the Beall valve prosthesis. Journal of Thoracic and Cardiovascular Surgery, 61, 393. 